NATIONAL LABORATORY

\title{
Measurement of Exterior Foundation Insulation to Assess Durability in Energy-Saving Performance
}

\section{April 2012}

Prepared by

Manfred Kehrer

Jeff Christian

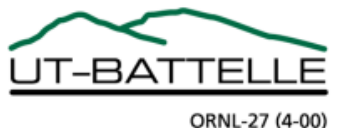




\section{DOCUMENT AVAILABILITY}

Reports produced after January 1, 1996, are generally available free via the U.S. Department of Energy (DOE) Information Bridge.

Web site http://www.osti.gov/bridge

Reports produced before January 1, 1996, may be purchased by members of the public from the following source.

National Technical Information Service

5285 Port Royal Road

Springfield, VA 22161

Telephone 703-605-6000 (1-800-553-6847)

TDD 703-487-4639

Fax 703-605-6900

E-mail info@ntis.gov

Web site http://www.ntis.gov/support/ordernowabout.htm

Reports are available to DOE employees, DOE contractors, Energy Technology Data Exchange (ETDE) representatives, and International Nuclear Information System (INIS) representatives from the following source.

Office of Scientific and Technical Information

P.O. Box 62

Oak Ridge, TN 37831

Telephone 865-576-8401

Fax 865-576-5728

E-mail reports@osti.gov

Web site http://www.osti.gov/contact.html

This report was prepared as an account of work sponsored by an agency of the United States Government. Neither the United States Government nor any agency thereof, nor any of their employees, makes any warranty, express or implied, or assumes any legal liability or responsibility for the accuracy, completeness, or usefulness of any information, apparatus, product, or process disclosed, or represents that its use would not infringe privately owned rights. Reference herein to any specific commercial product, process, or service by trade name, trademark, manufacturer, or otherwise, does not necessarily constitute or imply its endorsement, recommendation, or favoring by the United States Government or any agency thereof. The views and opinions of authors expressed herein do not necessarily state or reflect those of the United States Government or any agency thereof. 
ORNL/TM-2012/159

Energy and Transportation Science Division

\title{
MEASUREMENT OF EXTERIOR FOUNDATION INSULATION TO ASSESS DURABILITY IN ENERGY-SAVING PERFORMANCE
}

\author{
Manfred Kehrer \\ Jeff Christian
}

Date Published: April 2012

Prepared by

OAK RIDGE NATIONAL LABORATORY

Oak Ridge, Tennessee 37831-6283

managed by

UT-BATTELLE, LLC

for the

U.S. DEPARTMENT OF ENERGY

under contract DE-AC05-00OR22725 



\section{CONTENTS}

Page

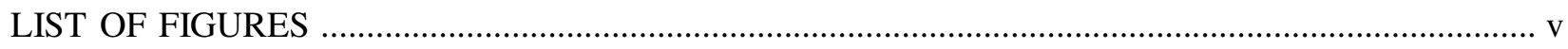

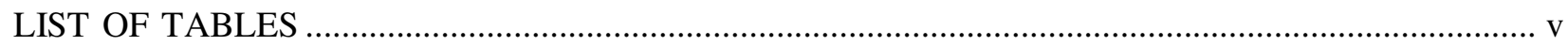

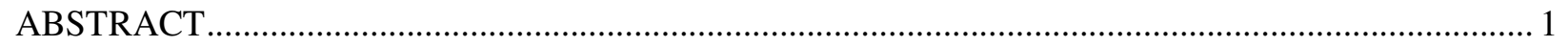

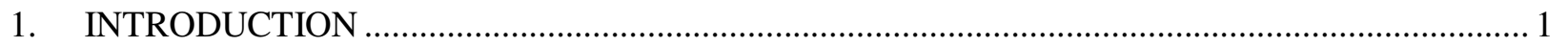

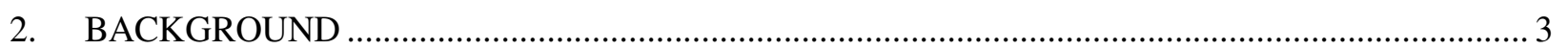

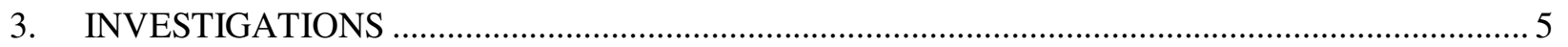

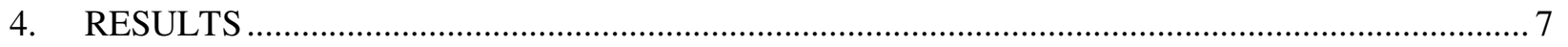

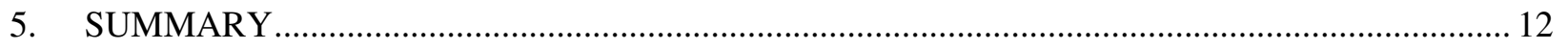

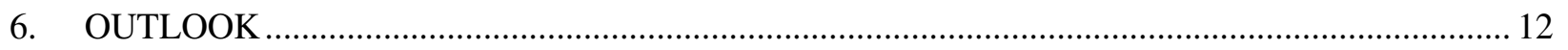

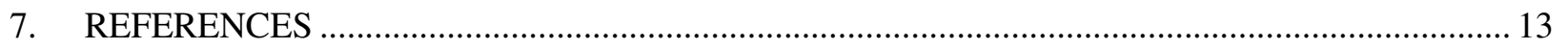





\section{LIST OF FIGURES}

Figure

Page

Fig. 1. Three typical foundation types. .................................................................................. 2

Fig. 2. Envelope Systems Research Apparatus at ORNL during construction in 1991_..................... 4

Fig. 3. Roof Thermal Research Apparatus at ORNL.................................................................... 5

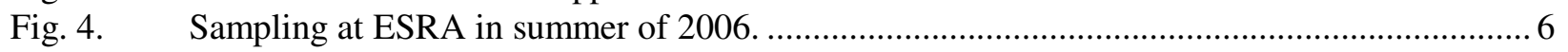

Fig. 5. R-values calculated from measured heat flux and temperature differences for the four different foundation insulation systems at ESRA at different times and depths. ..................... 7

Fig. 6. Moisture content vs. drying time for four samples of XPS insulation (top) and W\&D insulation (bottom) after excavation from ESRA............................................................ 8

Fig. 7. Moisture content vs. drying time for four samples of XPS insulation excavated from

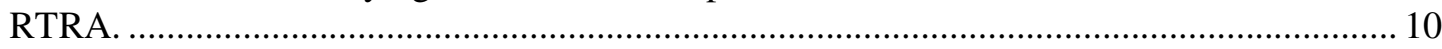

Fig. 8. Energy-saving performance of the foundation insulation systems at ESRA and RTRA over time. 11

Fig. 9. Hydro-vacuum excavation method used to dig a slot trench. 13

\section{LIST OF TABLES}

Table

Table 1. Thermal conductivity of the insulation layer at ESRA in 2006 at different moisture contents.

Table 2. Comparison of the ORNL test facilities ESRA and RTRA with regard to boundary conditions, potential influences on foundation insulation system durability, and results of 15 year observation of energy-saving performance 



\begin{abstract}
The foundation of a house is a sometimes ignored component of the building because of its low visibility. It is increasingly evident, however, that attention to good foundation design and construction significantly benefits the homeowner and the builder by mitigating future problems. Good foundation design and construction practice involves not only insulating to save energy but also providing effective structural design as well as moisture, termite, and radon control techniques as appropriate. Energy efficiency in housing is augmented by use of exterior slab and basement insulation, but high moisture content in the insulation material has led to concerns about its durability. The activity under this task was to extract six different exterior insulation systems that were characterized at installation and have been in the ground from 9 months to 15 years. R-value and moisture content were measured and inspections conducted for evidence of termite intrusion or deterioration. Based on the results, the durability of the various systems has been documented and assessments made of which systems appear to be best practice. Heat flux and temperature measurement data had been archived for some of the exterior insulation tests, thereby providing a unique opportunity to assess energy-saving performance and durability over the long term. The results show that the durability of foundation insulation systems depends on insulation type as well as on foundation type and local boundary conditions, the latter of which may have a marked influence on the durability of energy-saving performance.
\end{abstract}

\title{
1. INTRODUCTION
}

The current interest in foundation design and construction is primarily related to energy efficiency, although in some areas radon and moisture control are also of concern. Today's prospective home buyers increasingly demand healthy, energy-efficient homes that will provide the most comfort for their families at a reasonable price. In the past, the initial cost and the monthly mortgage payment were the critical criteria considered. Now, with rising energy costs, operating expenses are also a prime consideration and exert a major influence upon the more educated home buyer's decision. Home buyers want a home they can both afford to buy and afford to live in.

Home builders and code officials initially responded to these desires by providing more thermal insulation in the above-grade portions of the home. Attention to the foundation lagged for the most part, with most effort focused primarily on the foundation's structural adequacy. Recently, however, general awareness about health-oriented, energy-efficient foundation construction practices has increased in the United States. In 1989-90 several national building energy codes and standards were revised to recommend foundation insulation in moderate-to-cold U.S. climates (those with over 2500 heating degree days). Since then, subsequent code revisions have increased required levels of foundation insulation in many U.S. climates zones. Uninsulated foundations no longer represent 10 to $15 \%$ of a poorly insulated building's total heat loss; instead, an uninsulated, conditioned basement may represent up to $50 \%$ of the heat loss in a tightly sealed house that is well insulated above grade.

Concerns about the durability of basement insulation exist because of the likelihood of moisture intrusion and hence loss of energy-saving performance as well as termite infestation and decay of the materials. In general, moisture management schemes must control water in two states. First, since the soil in contact with the foundation wall is always at $100 \%$ relative humidity, foundation walls must deal with water vapor that typically migrates toward the interior. Second, liquid water entry must be prevented. Liquid water can enter from such sources as uncontrolled flows of surface water, a high water table, and capillary flow through subsurface foundation assemblies. Experimental studies (Zirkelbach et al. 2010) show that in exposed, extruded polystyrene foam (XPS) in a green roof system, up to 8 vol \% moisture accumulated within 10 years. Such a system is thought to have boundary conditions similar to those in basements. 
Numerical simulations by Künzel (1994) and Künzel and Kieß1 (1997) show moisture accumulation up to16 vol \% within 30 years in the same type of green roof systems.

The three basic types of foundations - full basement, crawl space, and slab-on-grade—are shown in Fig. 1. Houses may include combinations of these types. Information on a fourth type of foundation, the shallow or half-bermed basement, can be found in the Builder's Foundation Handbook (Carmody et al. 1991).

For the retrofit of a deep basement, there are generally two options-exterior or interior insulation. Exterior insulation has the advantage of keeping the foundation wall system warm and dry because the wall is on the interior (heated) side of the insulation. The major disadvantage is its costs as soil surrounding the exterior wall must be excavated and backfilled. Interior insulation has the advantage of being a less expensive solution. The disadvantage is the risk of moisture damage and mold growth between the wall system and the interior insulation resulting from insufficient sealing. A new option that possibly makes the preferable exterior insulation system cheaper and hence more attractive is discussed in this report.
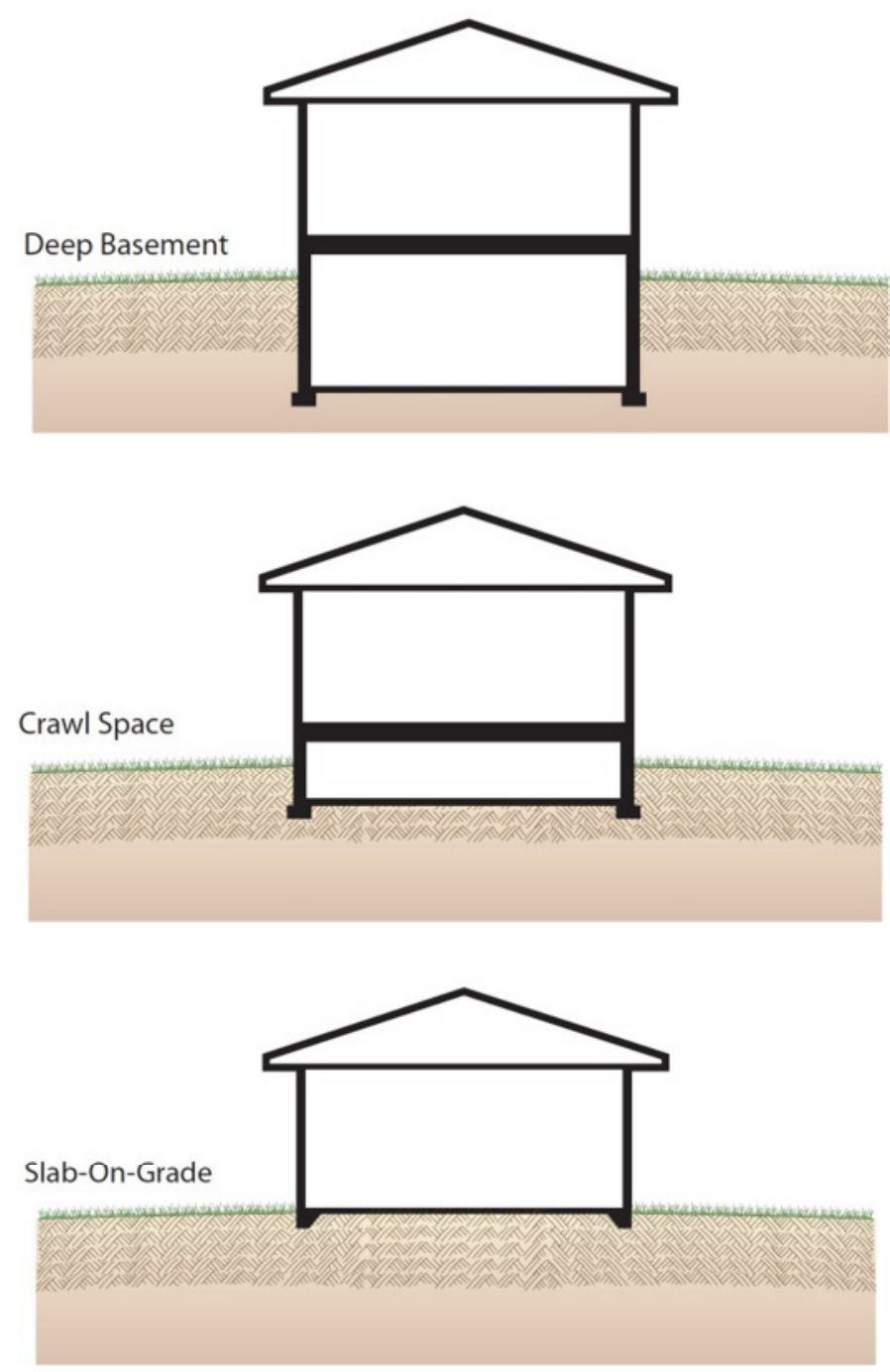

Fig. 1. Three typical foundation types. 


\section{BACKGROUND}

The studies conducted in this task are associated with the deep basement and slab-on-grade foundation types (see Fig. 1).

In 1991 four basement foundation systems were installed in the Envelope Systems Research Apparatus (ESRA) at Oak Ridge National Laboratory (ORNL). Figure 2 shows a picture taken prior to backfilling. The basement type of the ESRA is a deep basement according to Fig. 1 . The ESRA is a $30 \times 72$ foot test facility that has four test bays, allowing a side-by-side comparison of four different basement foundation systems. One of the foundation systems is a two-hollow-core concrete masonry unit that is 8 inches thick and solidly grouted but uninsulated. The second is a standard R-11 fiberglass batt wall with a 24 inch OC $2 \times 4$ wood frame wall. The last two foundation systems have exterior insulation, one with XPS blown with HCFC-141b and the other with 2 3/8-inch-thick fiberglass drainage board called W\&D. Each of the test walls is thermally isolated from the others by a 2 inch XPS wall positioned in a 12 inch trench under the slab and out 16 feet from the wall. The soil underneath and adjacent to the north-facing basement wall is backfilled with a very uniform clay soil, which makes for a uniform, porous media. This backfilled material extends at least 4 feet underneath the basement floor and out from the masonry test wall at least 25 feet. The XPS is positioned in the center of the ditch and backfilled with pea gravel to provide a hydrostatic break and minimize moisture flow. The precipitation water on ESRA is drained by gutters and downspouts. Each of the four 12-foot-wide foundation test walls has its own footer drain that runs separately to daylight. The finished grade slopes away from the structure 5\%, or 9 inches for the first 15 feet, from all four foundation test walls. The framed footer is 6 inches thick and projects out from the 8 inch block wall 4 inches on each side, making the footer 16 inches wide. A keyway is used to anchor the walls. Two-inch-diameter weep holes are provided through the footer on 4 foot centers. A through-joint flashing is placed on top of the footer to provide a capillary break.

The Roof Thermal Research Apparatus (RTRA) is another test facility at ORNL and is within walking distance of the ESRA. Figure 3 shows pictures of the RTRA. It has a slab-on-grade foundation and was insulated at the same time as the ESRA at the exterior side of the foundation wall by utilizing the same XPS insulation as used for the ESRA. The ditch at this test facility was backfilled with sand after retrofitting the foundation. 

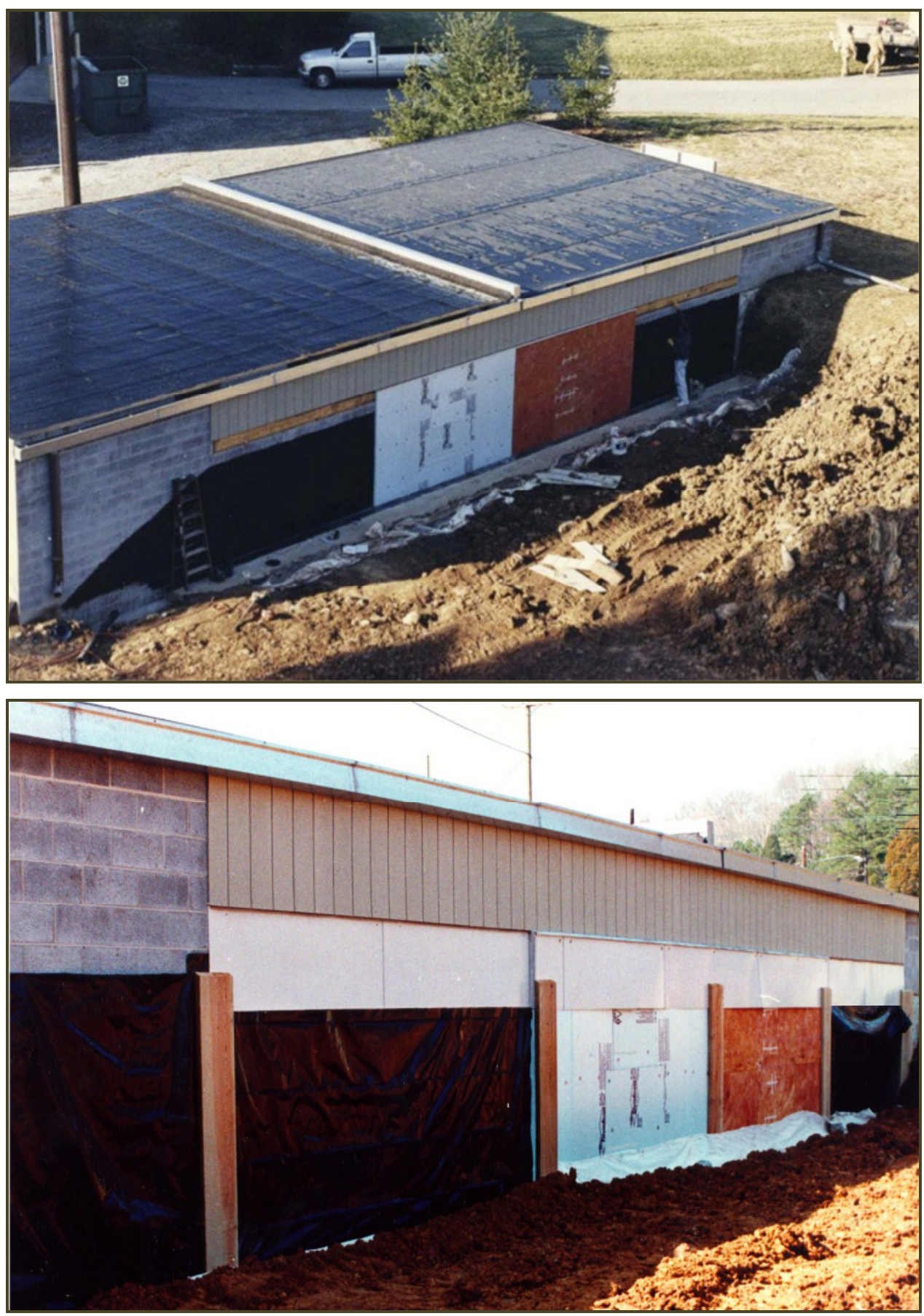

Fig. 2. Envelope Systems Research Apparatus at ORNL during construction in 1991. 

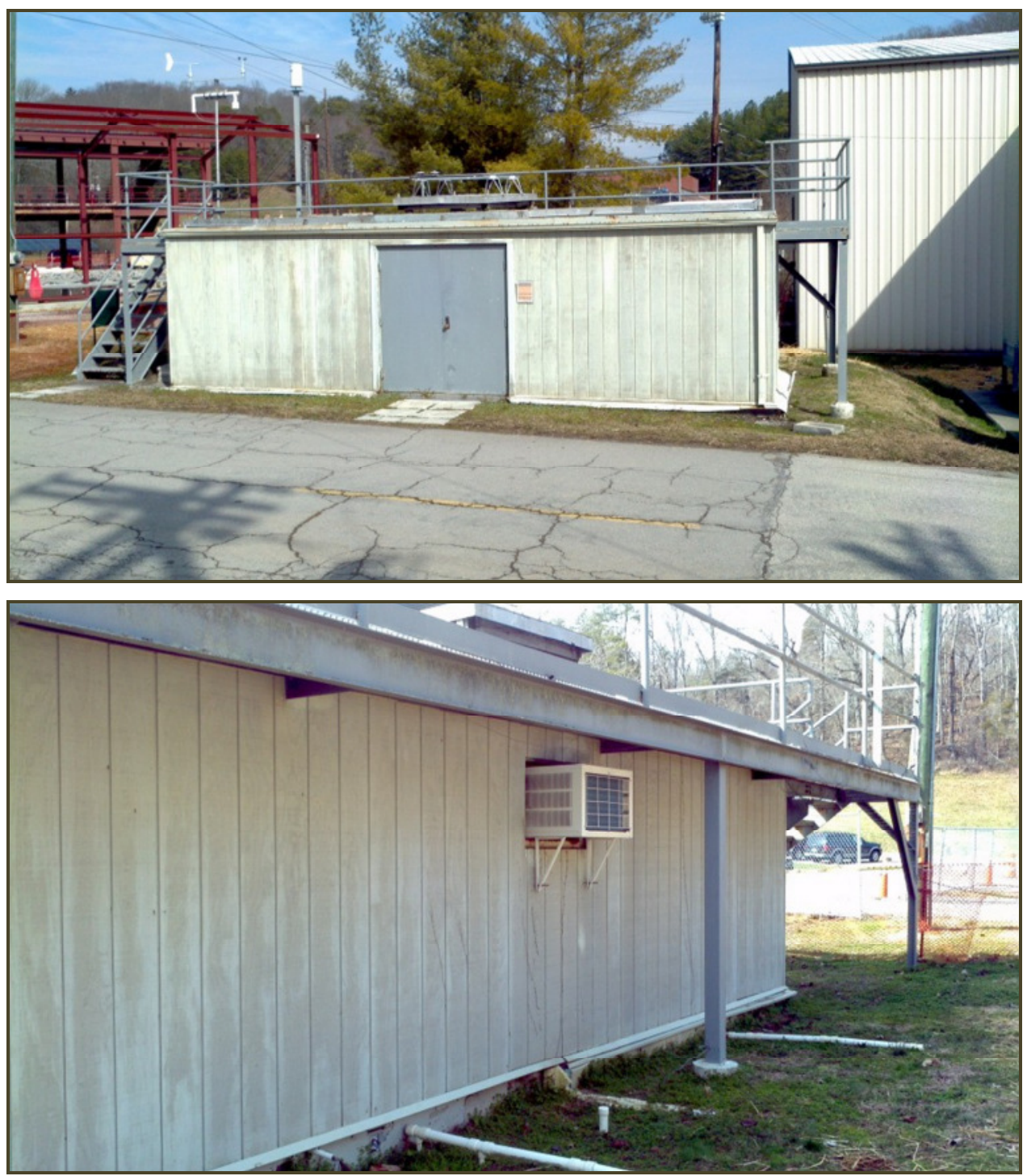

Fig. 3. Roof Thermal Research Apparatus at ORNL.

\section{INVESTIGATIONS}

Between 1991 and 1992 all four types of foundation insulation at the ESRA were measured continuously to assess their energy-saving performance. To accomplish this, heat flux transducers were installed on the interior surface of every insulation system as well as thermocouples on both sides of the assembly. As different below-grade levels may lead to different aging or durability behaviors, this instrumentation was set up at a depth of 24 inches from the top of the wall, which is above grade, and at 54 inches from the top of the wall, which is below grade.

Because the main concerns about basement insulation durability center around moisture intrusion and hence loss of energy-saving performance as well as termite infestation and material decay, additional investigations on the energy-saving performance of the foundation's two exterior insulation systems were accomplished in the summer of 2006. The backfill was again dug out, and samples of the XPS and W\&D insulation were taken to measure moisture content and energy-saving performance. Figure 4 shows 
pictures of this task. To measure the energy-saving performance of these possibly aged insulation systems, a guarded hot box according to ASTM Standard C177, "Test Method for Steady-State Heat Flux Measurements and Thermal Transmission Properties by Means of the Guarded-Hot-Plate Apparatus" was utilized for the insulation layer only. For both insulation types, XPS and W\&D, two samples (one above grade and one below grade) were prepared, and the thermal transmission according to ASTM Standard C177 was measured at their initial moisture content. After measuring, all samples were dried to derive their initial moisture content. Again, measurement according to ASTM Standard C177 was carried out for the dry sample of XPS insulation.

Also in the year 2006, the backfill at the RTRA test facility was dug out, and samples of the XPS board insulation were taken to measure both moisture content and energy-saving performance.
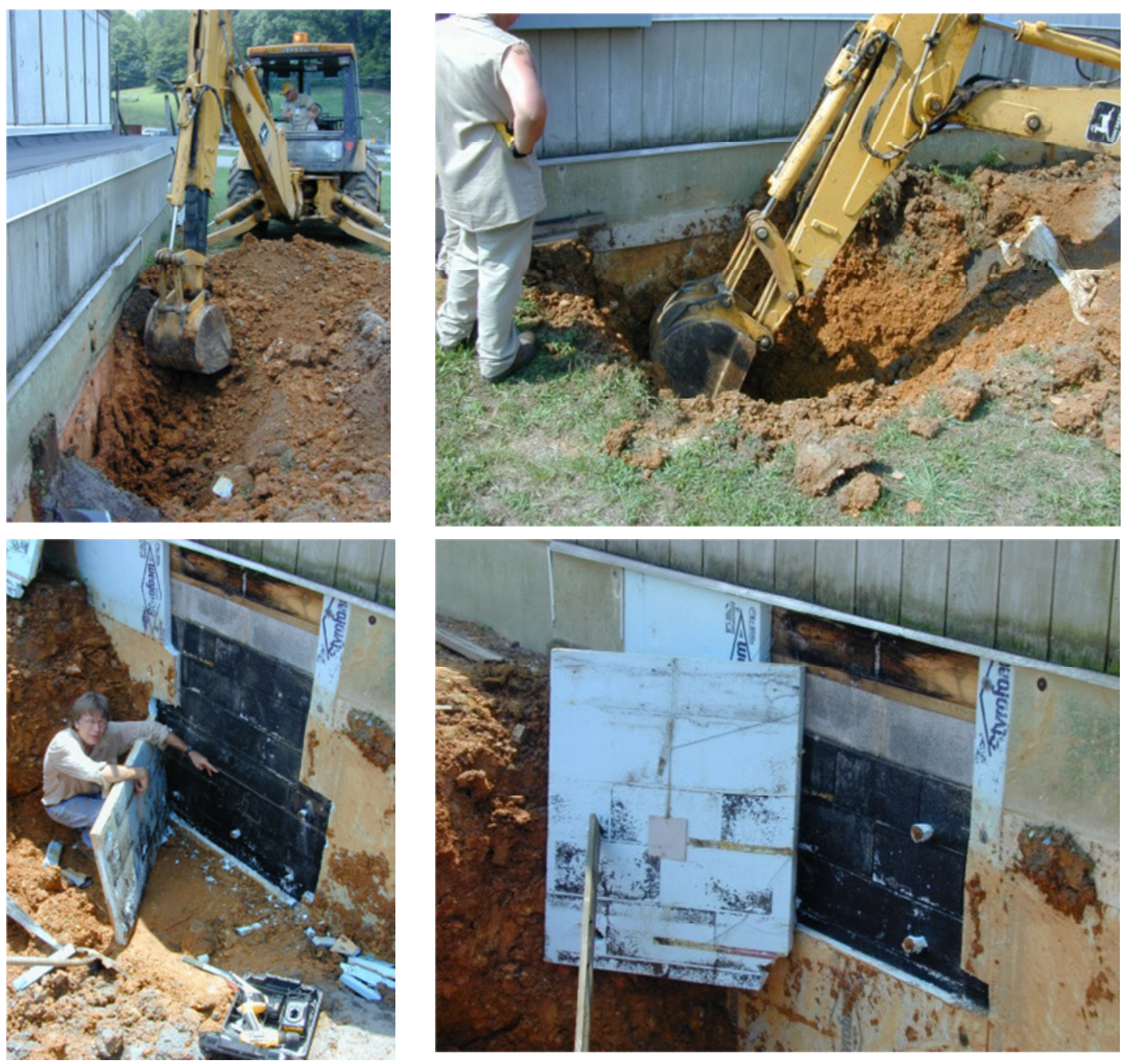

Fig. 4. Sampling at ESRA in summer of 2006. 


\section{RESULTS}

Figure 5 shows the results of the transient measurement of the energy-saving performance of the ESRA foundation insulation systems from 1991 to 1992. As expected, the performance of the insulated wall systems is much better than that of the uninsulated walls, which is evidenced by the high R-values for the insulated walls system. Furthermore, it can be seen that the insulated walls perform roughly the same. The performance over time seems to be constant, which means that no aging or durability issues exist within the first year. The influence of the below-grade depth is minor or has no systematic impact. Altogether, no durability issues are visible.

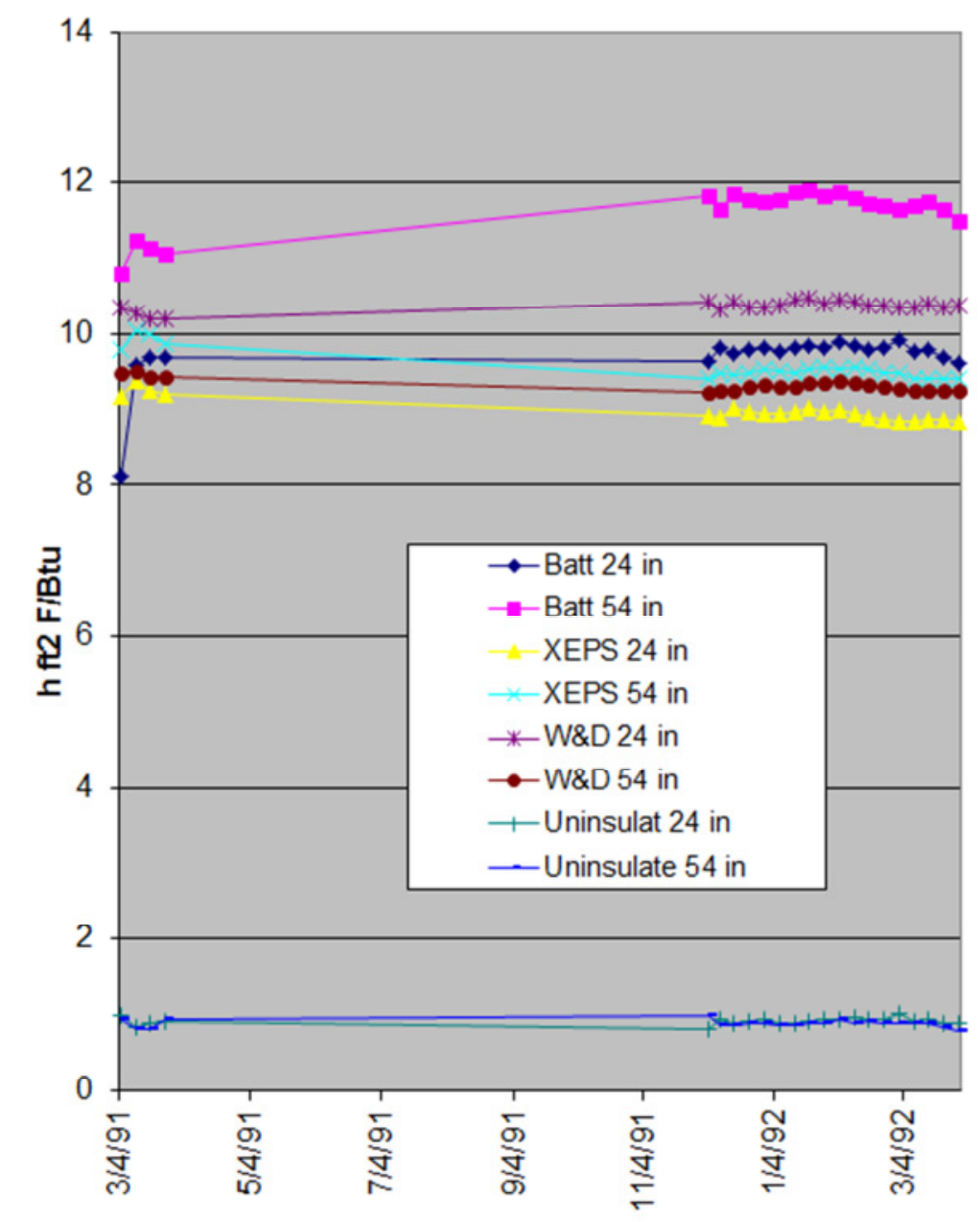

Fig. 5. R-values calculated from measured heat flux and temperature differences for the four different foundation insulation systems at ESRA at different times and depths.

Fifteen years later the area around the two exterior insulation systems at ESRA were dug out, and specimens of the XPS and the W\&D insulation were taken to once more investigate their energy-saving performance. As the specimens gained moisture during the previous 15 years, measurements of the thermal transmission were carried out with the specimens at their initial moisture content as well as after drying. Figure 6 shows the results of the drying process for the samples at ESRA in 2006. It can be 

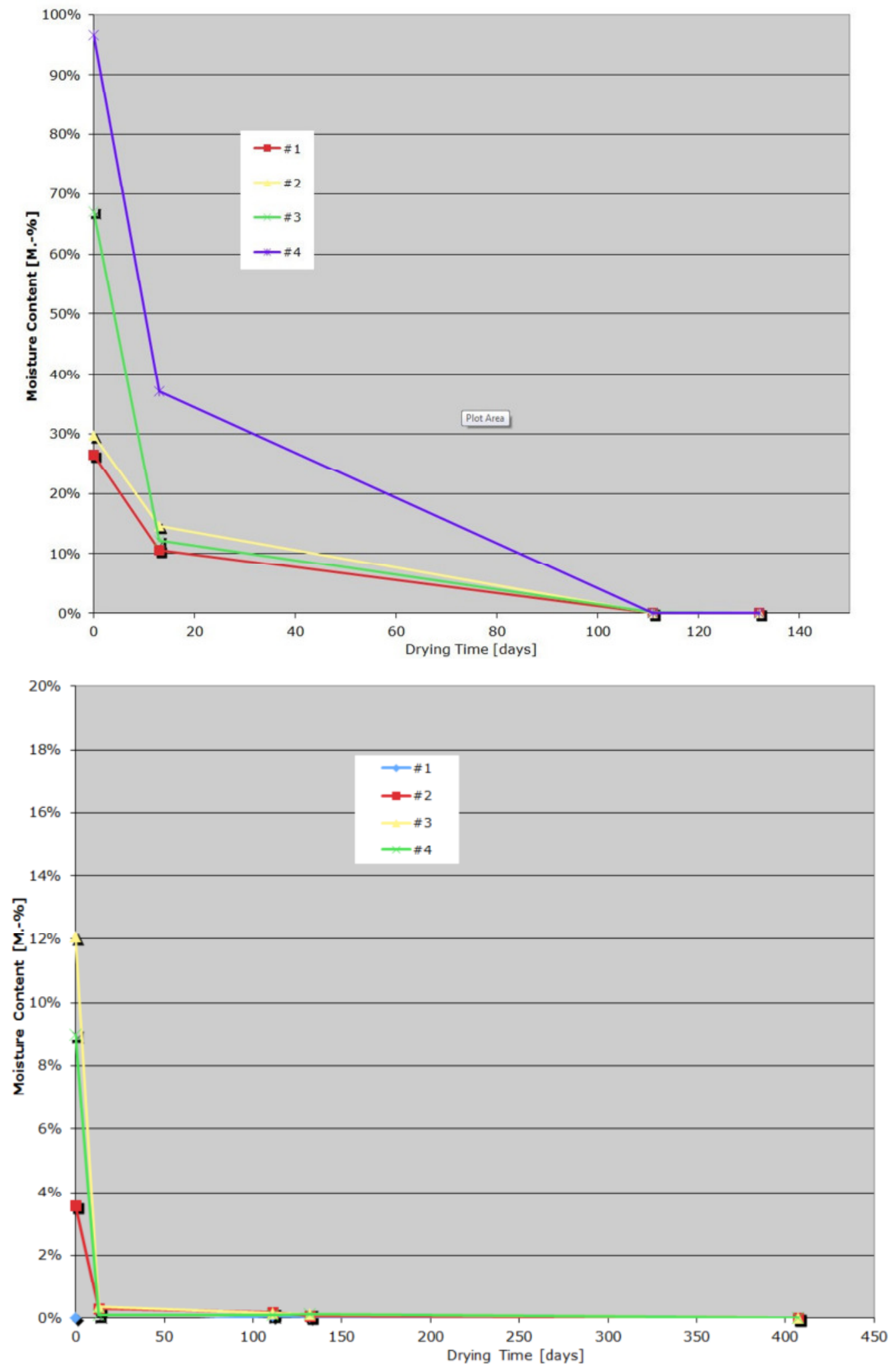

Fig. 6. Moisture content vs. drying time for four samples of XPS insulation (top) and W\&D insulation (bottom) after excavation from ESRA. Samples \#1 and \#2 are above grade; samples \#3 and \#4 are below grade. 
clearly seen that all samples of XPS insulation gained much more moisture during the 15 years of contact with soil moisture, especially samples \#3 and \#4 which were exposed below grade. Apparently, some drainage effect has taken place for the W\&D insulation, leading to lower moisture contents over the years. This can be explained by the different pore size structure of the two different insulation types (XPS and W\&D). Both have approximately the same porosity, but it is distributed at an unequal pore size range. XPS has many more small-sized pores compared to the W\&D fiberglass and hence has higher capillary suction forces. These capillary suction forces at smaller pore sizes are much higher than gravity and prevent moisture from draining out of the XPS to the water table. This is apparently possible for the moisture in $\mathrm{W} \& \mathrm{D}$ insulation as the larger pore sizes have only minor capillary suction pressure. The drying time for the XPS samples is slightly more than 3 months, which is much longer than the drying time for the W\&D insulation. This is due to the lower moisture content as well as the higher vapor permeability of the W\&D insulation, which enables a higher diffusion and evaporation rate.

Table 1 lists the results of the measurements for thermal transmission according to ASTM Standard C177 at different moisture contents. For XPS and W\&D insulation, the thermal conductivity and the R-value are shown. We can see that the relatively high initial moisture contents of the XPS, especially for the below-grade samples, have little impact on the energy-saving performance as their R-values are marginally lower at the initially higher moisture content. But overall, the energy-saving performance of both XPS and W\&D insulation is still good.

Table 1. Thermal conductivity of the insulation layer at ESRA in 2006 at different moisture contents

\begin{tabular}{|c|c|c|c|c|}
\hline $\begin{array}{l}\text { Insulation } \\
\text { Layer }\end{array}$ & $\begin{array}{l}\text { Thickness } \\
(\mathrm{mm})\end{array}$ & $\begin{array}{c}\text { Moisture } \\
\text { Content } \\
(\%)\end{array}$ & $\begin{array}{c}\text { Thermal } \\
\text { Conductivity } \\
(\mathrm{W} / \mathrm{mK})\end{array}$ & $\begin{array}{c}\text { R-Value } \\
\left(\mathrm{h} \cdot \mathrm{ft}^{2} \cdot \mathrm{F} / \mathrm{Btu}\right)\end{array}$ \\
\hline \multicolumn{5}{|c|}{ XPS Above Grade } \\
\hline \multirow[t]{2}{*}{$\# 1$} & 50.4 & $27 \%$ & 0.0319 & 9.0 \\
\hline & 50.4 & Dry & 0.032 & 9.0 \\
\hline \multirow[t]{2}{*}{$\# 2$} & 50.4 & $30 \%$ & 0.0318 & 9.0 \\
\hline & 50.4 & Dry & 0.032 & 9.0 \\
\hline \multicolumn{5}{|c|}{ XPS Below Grade } \\
\hline \multirow[t]{2}{*}{$\# 3$} & 50.9 & $67 \%$ & 0.0333 & 8.7 \\
\hline & 50.9 & Dry & 0.033 & 8.9 \\
\hline \multirow[t]{2}{*}{$\# 4$} & 50.8 & $97 \%$ & 0.0343 & 8.4 \\
\hline & 50.8 & Dry & 0.033 & 8.6 \\
\hline \multicolumn{5}{|c|}{ W\&D Above Grade } \\
\hline$\# 1$ & 61.0 & $0 \%$ & 0.0338 & 10.2 \\
\hline$\# 2$ & 61.0 & $4 \%$ & 0.0339 & 10.2 \\
\hline \multicolumn{5}{|c|}{ W\&D Below Grade } \\
\hline$\# 3$ & 61.0 & $12 \%$ & 0.0341 & 10.2 \\
\hline \#4 & 55.9 & $9 \%$ & 0.0342 & 9.3 \\
\hline
\end{tabular}

At the other test facility, RTRA, things are different. When XPS samples from below grade were dug out, their initial moisture content was much higher. Figure 7 shows the drying behavior after the first measurement for the thermal transmission according to ASTM Standard C177. The drying times for these 
samples are close to 6 months and almost twice as long as for the samples from the ESRA facility. The impact of these very high moisture contents to the energy-saving performance is obvious in Fig. 8.

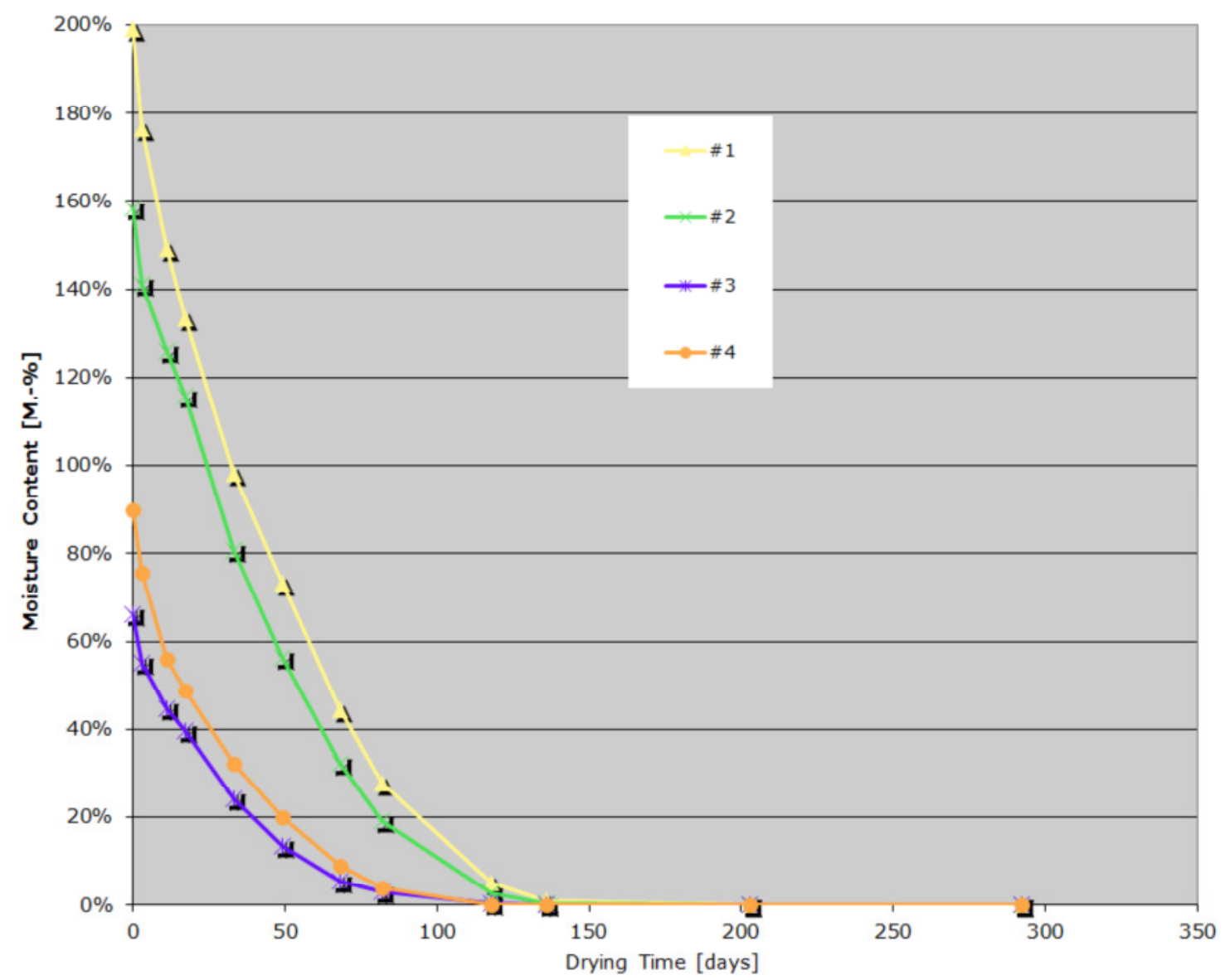

Fig. 7. Moisture content vs. drying time for four samples of XPS insulation excavated from RTRA. All samples are from below grade. 


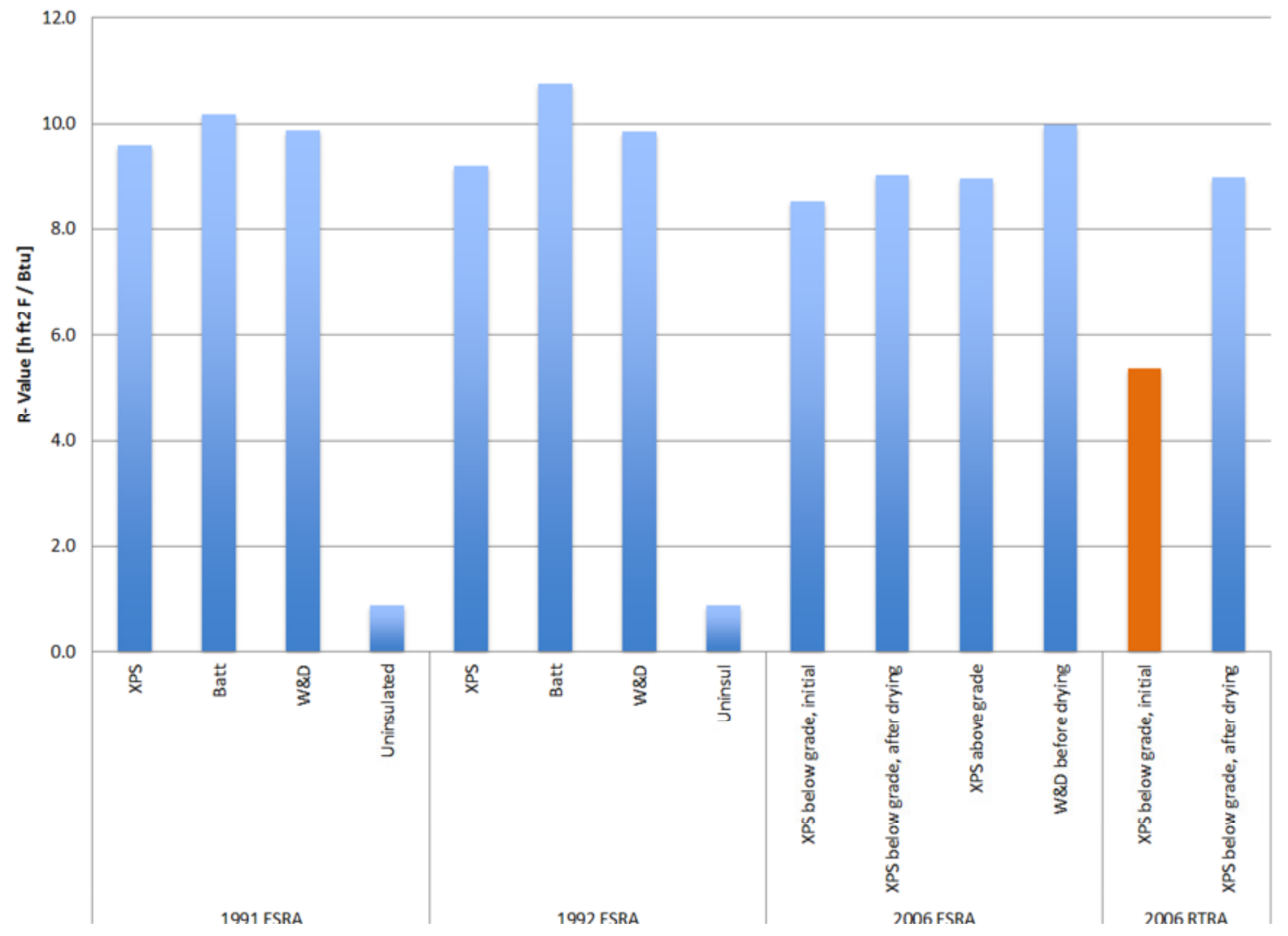

Fig. 8. Energy-saving performance of the foundation insulation systems at ESRA and RTRA over time. The results for 1991 and 1992 were derived from transient in situ measurements in Fig. 5. The results for 2006 were derived from ASTM Standard C177 measurements.

Figure 8 shows all results for energy-saving performance over the year, for different facilities and different foundation insulation system at different moisture contents. Note that the results for 1991 and 1992 were derived from transient in situ measurements in Fig. 5. The results for 2006 were derived from ASTM Standard C177 measurements. We can see that the energy-saving performance of the uninsulated wall is minor as expected. Furthermore we can see that the moisture content of XPS at ESRA in 2006 had an influence, but it recovered after drying, which led to the conclusion that besides moisture, no other aging process has taken place. Nevertheless, the loss of energy-saving performance is about $10 \%$. The durability of energy performance of the above-grade XPS and the above- and below-grade W\&D from ESRA in 2006 is apparently not influenced by moisture or aging, and hence no durability issue for energy-saving performance is visible. The result at RTRA for thermal transmission according to ASTM Standard C177, that is, an R-value of $5.4\left(\mathrm{~h} \cdot \mathrm{ft}^{2} \cdot{ }^{\circ} \mathrm{F} / \mathrm{Btu}\right)$, equates to a $44 \%$ loss of energy-saving performance compared to a similar sample from ESRA in 1991 (R-9.2), which is conspicuous in Fig. 8. Here too, after drying, the energy-saving performance of the sample recovers close to $100 \%$. Again, except for moisture, other aging processes have apparently not taken place or exert only a marginal influence. On the other hand, even if no real material aging has taken place, the loss of energy-saving performance due to elevated moisture content must be rated as a loss of durability because the main purpose of an insulation material, to reduce energy losses through the building envelope, is lost.

Apparently, the different boundary conditions at ESRA and RTRA have an impact on the moisture contents of their foundation insulation systems and hence have an influence on their energy-saving performance. Otherwise, the different behaviors exhibited by the same XPS material cannot be explained. Table 2 lists all known essential differences between the two test facilities as well as the overall results of 
the investigations. As the deep basement foundation system is heated during the winter, this energy helps to warm at least the interior half of the insulation layer and hence encourages moisture to evaporate, which leads to a lower moisture content. Existing gutters and downspouts at ESRA also help to lower the moisture load in the soil around the foundation insulation system and in the insulation. So apparently these boundary conditions are the controlling factors for the durability of the energy-saving performance in the foundation insulation systems. It is therefore recommended that the instructions in the Builder's Foundation Handbook (Carmody et al. 1991) be followed with regard to landscaping.

Table 2. Comparison of the ORNL test facilities ESRA and RTRA with regard to boundary conditions, potential influences on foundation insulation system durability, and results of 15 year observation of energy-saving performance

\begin{tabular}{lll}
\hline & \multicolumn{1}{c}{ ESRA } & \multicolumn{1}{c}{ RTRA } \\
\hline Foundation type & Deep basement & Slab-on-grade \\
Heating of the insulation from indoor possible & Yes & Marginally \\
Gutters, downspouts & Do exist & Do not exist \\
Loss of energy savings performance, XPS & $10 \%$ & $44 \%$ \\
Durability issues, XPS & Minor & High \\
Loss of energy savings performance, W\&D & None & N.A. \\
Durability issues, W\&D & None & N.A. \\
\hline
\end{tabular}

\section{SUMMARY}

Different foundation insulation types at two ORNL test facilities were investigated from 1991 to 2006. The main purpose was to measure the performance for energy savings and to determine whether moisture or other aging phenomena influence the durability of these systems. The thermal transmission was tested by transient in situ measurements and by measurements according to ASTM Standard C177. Long-time durability indicators for energy-saving performance were derived from these measurements, showing that an exterior foundation insulation system made of fiberglass (W\&D) has fewer durability issues than a system incorporating XPS. Furthermore, the durability of an XPS-based system seems to depend greatly on other boundary conditions, such as foundation type and the existence of gutters and downspouts. In the worst case the loss of energy-saving performance can be more than $44 \%$. It is therefore recommended that instructions in the Builder's Foundation Handbook (Carmody et al. 1991) be followed with regard to landscaping and application of waterproofing layers.

\section{OUTLOOK}

Compared to interior insulation, the exterior insulation still has the disadvantage of being very expensive. The costs are dominated by excavation, backfilling, and landscaping of soil surrounding the exterior wall. To mitigate this, the cost-dominating factor of excavation must be reduced to make an exterior insulation more attractive and to achieve shorter payback times. Recent improvements in techniques may fulfill this goal. Figure 9 shows one of these newly developed techniques. Here, we see that the excavation has been carried out by using a hydro-vacuum method of slot trenching. Water has been mixed into the soil to make the soil more fluid so that it can be extracted by sludge-collecting vehicles. So far, the technique has been applied only to excavation for pipe laying but has been highly successful. A major benefit of this option is that no costs will be incurred for landscaping after backfilling. On the other hand, problems may 
occur from water being added to the soil; the moisture content of the foundation wall will likely be elevated, and dry-out must be guaranteed to prevent moisture damage.

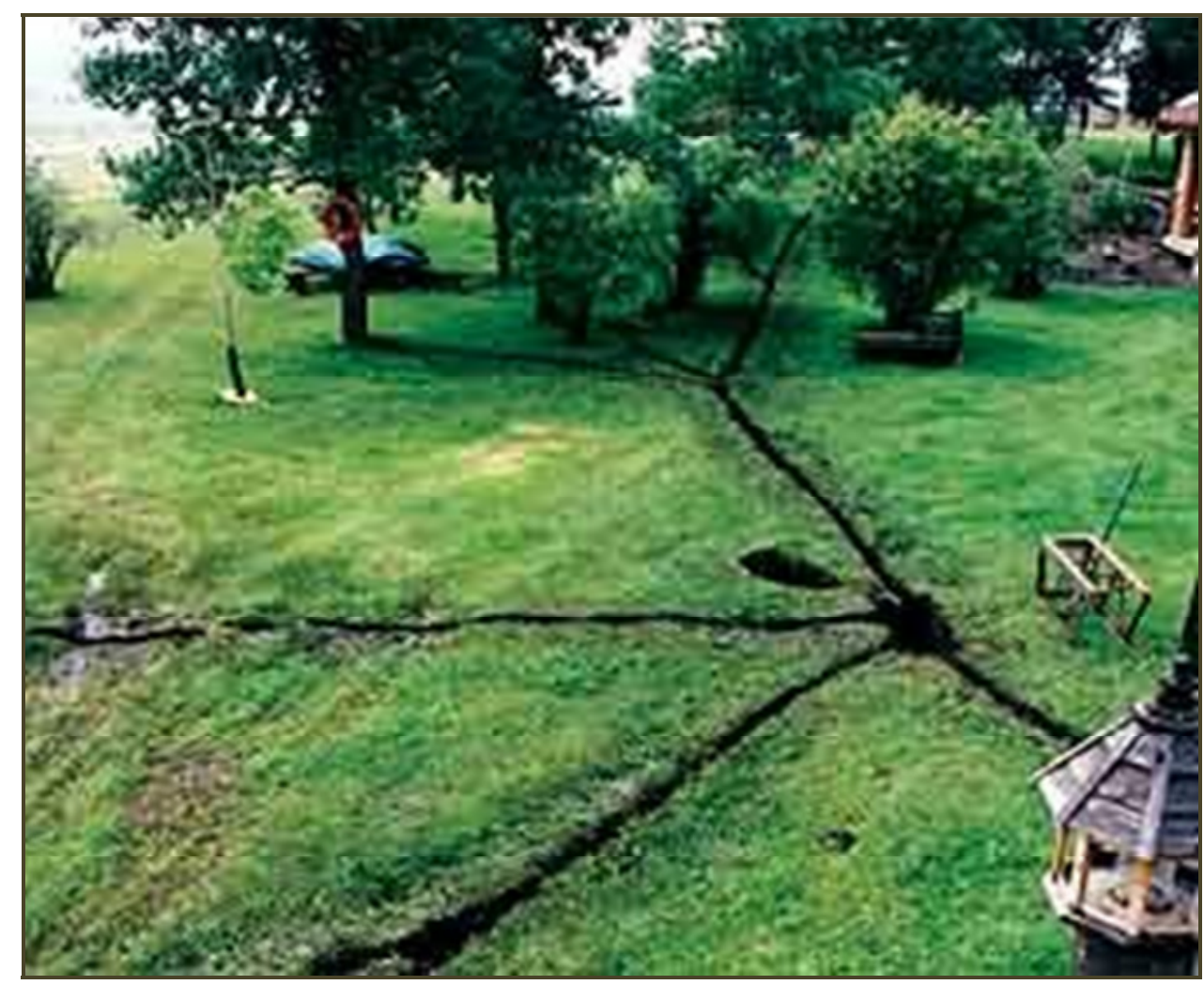

Fig. 9. Hydro-vacuum excavation method used to dig a slot trench.

\section{REFERENCES}

Carmody, J., J. Christian, and Kenneth Labs. 1991. Builder's Foundation Handbook, ORNL/CON-295, Oak Ridge National Laboratory.

Künzel, H.M. 1995. Simultaneous Heat and Moisture Transport in Building Components-One- and Two-Dimensional Calculation Using Simple Parameters, Fraunhofer Institute of Building Physics, ISBN 3-8167-4103-7.

Künzel, H.M. and H. Kieß1. 1998. Moisture behaviour of protected membrane roofs with greenery, Minutes and Proceedings of Working Commission W40 Meeting in Kyoto, Japan, 1997, CIB Proceedings 213, International Council for Building Research, Studies and Documentation, Rotterdam.

Zirkelbach, D., B. Schafaczek, and H.M. Künzel. 2010. Long-term hygrothermal performance of green roofs, in Proc. Buildings XI, ASHRAE, Atlanta. 
